\title{
Revamping the Environment for National Development: A Lexico- Semantic Reading of Niyi Osundare's The Eye of the Earth
}

\author{
Mary Enwelim-Nkem Okoh \\ Delta State Polytechnic, Nigeria \\ Nkemmay@Yahoo.Com
}

DOI: http://doi.org/ 10.36892/ijlls.v3i1.556

$\begin{array}{ll}\text { Received: } & \text { Abstract } \\ \text { 14/04/2021 } & \text { Environmental poetry is relatively young in the literature of the Nigerian } \\ \text { Accepted: } & \text { literary writers and critics. Literary scholars of an earlier generation before } \\ \text { Osundare - Soyinka, Okigbo, and Okara have dwelt more on the themes and } \\ \text { language of cultural heritage, cultural conflicts, colonial and post-colonial } \\ \text { political, socio-economic and religious issues. They barely scratched around } \\ \text { the themes of environment and ecology. More so, their language may be } \\ \text { Environment poetry, } \\ \text { language, semantics, } \\ \text { innovation, ecology } \\ \text { exploration of Osundare's innovative and full-scale venture into pivotal issues } \\ \text { of the environment that have become of utmost concern nationally and } \\ \text { internationally in contemporary times. Also of interest in this study is } \\ \text { Osundare's efforts to redefine the diction of Nigerian poetry to reach a wider } \\ \text { audience. Osundare's poetry collection, The Eye of the Earth is our focal text. } \\ \text { It has been observed that critical studies on this collection are largely centered } \\ \text { on literary interpretations. Lexico-semantic exploration of this collection can } \\ \text { be considered inadequate, which necessitated the present study to strike a } \\ \text { balance in deciphering Osundare's language and thematic preoccupations. } \\ \text { This study is anchored on systemic functional linguistics (SFL) and eco- } \\ \text { criticism theory with insights from lexical-semantic theory. Poems of } \\ \text { environmental background are purposively selected from the collection. The } \\ \text { study reveals Osundare's tactical manipulation of "common" language in } \\ \text { exposing man's pernicious activities in the natural environment. In a similar } \\ \text { manipulative skill in language use, the study unveils consequential roles } \\ \text { imperative for a man to obviate his adverse activities on nature in order to } \\ \text { achieve development at different spheres of life. }\end{array}$

\section{INTRODUCTION}

Critical studies in ecological and environmental literary writings started in the Nigerian literary and linguistic scene. Some few decades ago. However, it must be noted that themes relating to nature and environment or ecology have consciously or unconsciously been part of some Nigerian literary works of the generation preceding Osundare`s. By implication, nature and environmental poetry have been on Nigerian writers' literary background from time past. Buttressing this assertion, Agofure (2016, p.vii) observes that some early Nigerian poets "were concerned with environmental deterioration, [but] they did not explore it with the same critical idiom, tenor and thrust" associated with the environmental poetry of Osundare in The Eye of the Earth. This position is amplified by Owomoyela $(1979, \mathrm{p} .2)$ in his conceptualization of myth as linked to environment. He explains that myth covers "the interrelationships of all 
things that exist and provide for the group and its members a necessary sense of their place in relations to their environment and the forces that order events on earth"

Agofure (2016) further instantiates this point that a critical review of Nigerian first generation literary writers will confirm the occurrence of environmental features in their writings such as Things Fall Apart by Chinua Achebe, A Dance of the Forest by Wole Soyinka and The Concubine by Elechi Amadi. These texts feature some forms of ecological organization in the structure and orderliness of human and non-human aspects of the natural environment before the invasion of the colonialists.

From the foregoing propositions, it is largely incontrovertible that nature and environmental literature has developed a form of discourse that has become of interest to scholars hence, the avalanche of linguistic studies of poems, drama and prose of this background. Notable Nigerian environmental literary writers include Niyi Osundare, Tanure Ojaide, Nnimmo Bassey, Odia Ofeimum, Ken Saro-Wiwa (Nwagbara, 2013; Agofure, 2016). Osundare is one of these leading proponents of environmental poetry, whose literary artistic innovation appears to be the most distinctive among the new generation of poets because of his peculiar choice of diction, is our focus in this study. It must be noted that the innovative demystification of the poetic language and the resolution of issues in favour of the masses, in the spirit of Marxism is a remarkable development in the poetry of Osundare that echoes his popularity as the people's poet. (Anyokwu, 2013).

The Eye of the Earth is the first major nature and environmental poetry collection published by Osundare. As a result, it has been critically examined by many scholars both from literary and linguistic perspectives. Some of these studies include Anyokwu (2013), Elgezeery (2013), Anyokwu (2015), Dick (2016) Agofure (2016) and Oloko (2017). In spite of the richness of these studies, it is observed that lexico-semantic features in The Eye of the Earth have not been addressed detailedly. From the literature, these features appeared to have been swallowed by analysis of the other linguistic features. The present study attempts to fill this vacuum by giving detailed attention to the selected poems' lexico-semantic qualities to enhance greater understanding of Osundare`s thematic pre-occupations, language, and style.

\section{LITERATURE REVIEW}

Scholars of various background, especially from the fields of language and literature, have engaged at different times in scholarly and critical exploration of the style, language, techniques and thematic pre-occupations of literary works of Niyi Osundare. His poetry collection, The Eye of the Earth, a onetime Commonwealth poetry prize winner, has received great and interesting research attention over the years. For instance, applying Halliday`s (2004) theoretical model of grammatical metaphor, steeped in the meta-functions of systemic functional linguistics, Oloko (2004) examines two poems from The Eye of the Earth. These include, "What the Earth Said" and "The Rocks Rose to Meet me". These poems are subjected to process analysis resulting in the predominance of the material process. Oloko argues that the persistent occurrence of the material process in the poems is a deliberate tool by Osundare to express his experience and reaction to man's inhumanity to man. And also, a linguistic act of speaking out against the oppression of the masses by the ruling class. Most remarkably, Oloko observes that Osundare has used these poems to voice out his concern over the destruction of mother earth and maltreatment of the masses as well as workers in factories and industries.

Similarly, Anyokwu (2013) investigates the graphological background and its relevance in Osundare's poetry. Anyokwu anchors his analysis on tenets of semiotics. He opines that Osundare exploits: 
the phonological and sonic features of the Yoruba language

whose expropriation constitutes the figural and epistemological

background of his poetry... [combining] his native oral poetic

source and, of course, the western poetry tradition generally

and English poetry in particular (p.3).

The inputs of Yoruba orature, Anyokwu remarks, is a truism premised on the position that African societies and cultures are fundamentally communist and as such, "it is inconceivable for the oral raconteur to create his tales, songs, or poems without his audience playing a vital role...." (p.5).

In the study, Anyokwu finds that Osundare greatly deploys alliteration, repetition, assonance, consonance, onomatopoeia, and parallelism to achieve phono-aesthetic and semantic purpose. He illustrates with ageere, amokoyeri, elulu, agbegilodo, oro, iroko, patanmo, olosunta (The Eye of the Earth), "swagger like a soldier/prattle like a poetaster", "the benevolence/of the body politic" (Songs of the Market Place). Other graphological features found in the study according to Anyokwu, are cramping, blending and neologism.

Deploying eco-poetry tools, Nwagbara (2013) explores how Osundare "unearths, the commodification of social-economic relations, leadership failure, environmental/ecological immiseration and endangered nature mediated through (global) capitalism" (p.196) in The Eye of the Earth. Nwagbara avers that Osundare is committed to the mission of salvaging Nigerian's environment. As a result, Osundare uses The Eye of the Earth to expose environmental injustice and unrestrained materialist pursuit ravaging nature, biodiversity and the ecology. Nwagbara draws the conclusion that Osundare`s pre-occupation in The Eye of the Earth is de-commodification of nature, in addition to re-organising Nigerian socio-economic realities through the medium of eco-poetry.

In the same vein, Dick (2016) notes that Osundare`s The Eye of the Earth centres on the issue of destruction of the agrarian culture by an implanted capitalist structure. The importance of Dick's (2016) study lies in his corroborative view with Jeyifo (1988) that Osundare has a systematic pattern of demystifying the language of poetic delivery. This style makes Osundare evolve "a defining aesthetics and writes a revolutionary poetry and poetry of revolution" ( $p$ $.37)$.

In another study, Dick (2018) investigates graphology as an expressive poetic style of deviation in Osundare's poetry. The study reveals that Osundare employs the graphic craft in The Eye of the Earth, for example, as a way of expressing a conceptual idea centreing on the harm that has been visited on the natural environment. The words depicting this concept are captured in "scrambling", "jumbling" and "slanting" of the words and lines of the poem to buttress his argument.

From the foregoing linguistic studies and many more recorded in the field of literature, it is observable that detailed interpretations of the lexico-semantics of Osundare's The Eye of the Earth is tangentially addressed. This area of study is the engagement we have set out to achieve 
in this study, particularly with the view of ascertaining its relevance to Osundare`s goals in this collection.

\section{METHODOLOGY}

The Eye of the Earth is a poetry collection in three movements: "Back to Earth", "Rainsongs" and "Homecall". We have purposively selected four poems for analysis from the last movement, "Home call". This selection is premised on the consequential connection between the poems in this movement and issues of environmental concern vis a vis the aesthetics of the linguistic tools of conveying Osundare's thematic preoccupations.

The poems selected include "Excursion" "Farmer Born", "Ours to Plough, not to Plunder" and "Our Earth will not Die". Two theories have been synthesized for analysis- systemic functional linguistics (SFL) and eco-criticism theory. SFL for its functional value in interpreting the language of the poems and eco-criticism theory for its focus on the interrelatedness of environment and literature. Insights from Lyons (1977), Cruse (1986) and Adegbija (1989) on lexical semantic features are relevant for categorization and enrichment of the analysis.

The analysis is qualitative and focuses on detailed lexical and semantic interpretations of the poems. These theoretical tools are deployed simultaneously for comprehensiveness and vividness in exposing environmental issues and strategies for tackling them for national development.

\section{THEORETICAL BACKGROUND}

Two theories of relevance in this study have been harmonized for the interpretation of data. They are systemic functional linguistics (SFL) popularized by M.A.K Halliday (1994) and ecocriticism associated with Glotfelty (1996). Systemic functional linguistics (hence forth, SFL) is a theory of language which places emphasis on the functional elements of language. It reveals the intimate relationship between language and situation. It also recognizes the interdependency of style, meaning and context of situation (Butler 1985).

From Butler's disposition, context is crucial to SFL. In effect, this model recognizes context of culture and context of situation. Context of situation is elaborated to cover register and its features of field, tenor and mode. Context of culture relates to the genre of a communicative relationship or event. All these features culminate to ascribing meaning to a text, utterance or situation. For Halliday, the totality of meaning is important and basically, can be realized in a social situation. Unlike Chomsky, Halliday has little interest in what goes on inside people`s head. Incidentally, this is the dimension from which systemic functional linguistics is viewed mostly. "Language is functional in the sense that it is designed to account for how the language is used (Halliday 1985,p. xii). In Halliday`s view, grammar is a network of systems of interrelated contrasts; in other words, systems that interact to build meaning in a language (Lamidi 2000; Osisanwo, 1999). In language generally, there is usually a set of choices available to language users. These choices are paradigmatically and syntagmatically constructed. The very choice made to a large extent, dependent on the variables of the context of situation.

Exploring paradigmatic and syntagmatic relationships in the context of this study, insights from Lyons (1977), Cruse (1986) and Adegbija (1989) are important. We exploit their relevance in connection to lexical relations and lexical semantic features essential to this study's linguistic domains: lexeme and semantics. 
Stringer (2019) gives a clear definition of lexical semantic components of linguistics as dealing with essential features of word meaning and the semantic relations between words, in addition to the ways in which word meaning is related to syntactic structure. In essence, lexical semantics are interested in how meaning is encoded and how word meaning relates to sentence meaning.

Murphy (2016) argues that lexical semantics may be defined as the study of word meaning but in practice, the focus is on content words as opposed to the meanings of grammatical words. Murphy further argues that even though lexical semantics focuses on content words, such words cannot be studied "in an agrammatical vacuum". That is, the meaning contributions of grammatical words help the content words to achieve balance of meaning.

Aligning with Murphy (2016), every word employed by Osundare in the selected poems, content or grammatical is important for a comprehensive interpretation of the poems. Merging insights from scholars earlier cited on lexical semantic features, some of these categorizations will be deployed in the analysis synonymy, antonym, hyponymy, transfer, semantic shift, coinage, clipping, conversing etcetera.

The second major theory for this study is the eco-criticism theory. This theory became promulgated by Cheryll Glotfelty (a professor of literature and environment) via the publication of The Ecocriticism. Reader: Landmarks in Literary Ecology, which she co-edited with Harold Fromm 1996. Remarkably, the term eco-criticism did not begin with Glotfelty and her research colleagues. William Rueckert is believed to have coined the term in 1978, which he defines as the application of ecology and ecological concepts to the study of literature (Glotfelty and Fromm, 1996). However, it was only in 1990s that eco-criticism emerged as a separate discipline; although, it is a fact that the relationship between man and his environment had always been an area of interest to literary critics (Barry cited in Jimmy 2015). Since its inception, many scholars have made notable contributions to its development. These include Shepard Paul (1969), Evernden Neil (1985), Worster Donald (1993), Dobie (2009), and Harold Fromm (2009).

Of particular importance in these works are the recommendations made by Dobie (2009, p.244) that a researcher engaging in eco-criticism study should be concerned with:

i. What insights about the natural world does the text or writer [being analysed] have to offer?

ii. Does it raise questions or issues about nature or the environment that readers should be concerned with?

iii. Does the work deal with environmental issues that are addressed in the study of history, philosophy, psychology, art or ethics?

iv. What has been over looked in traditional readings that can enrich public awareness of humankind's impact on the natural world?

Encapsulating these views, eco-criticism strives to challenge the status quo to change the injustices that are meted out on the environment by man. Thus, it is a revolutionary theory that tries to retrace man`s steps and stop him from destroying his environment. 
In the African continent, the concept of environment is viewed differently. The Africans include the land, the super-natural forces, religious beliefs, festivals, and their ideas about the world. (Gogoi 2014). In the light of the foregoing propositions, Moolla (2016) recommends that an African eco-criticism must be informed by a specific material and cultural conditions on the continent of Africa and not simply drawn on a supposed more universal post-colonial framework. African-focused eco-criticism should include its tenets, criticisms on the impact of colonialism, neo-colonialism, and globalization on various African environments ( Wu 2016).

\section{DATA ANALYSIS}

Reiterating the structure of our analysis as captured in the methodology, we are restricting to the poems purposively selected from the last movement according to the form Osundare organized the poems. In his preface, poems in this movement reminisce the original African environment, depict the present state of the environment and express fears for survival in the future by Nigeria in particular and the world in general. Osundare consoles himself that with deliberate efforts by mankind, human environment can be revived for the good of man.

\subsection{Excursion}

The poet personal recalls his past experiences and encounters as he goes on a poetic excursion into the past. The past was beautiful and natural with all the pleasurable experiences of "tireless treading" (line 1) in "bush paths" (line 1); attractive sight of nature`s endowment such as "dandelions" (line3) "ripening yams" (line 6) movement of leguminous plants, butterfly playing with flowers, "noonward sun" (line 22) and the general fragrance of naturalness surrounding the environment.

The deployment of the determiner "the" which runs consistently in stanzas 2,3, and 4 indicates that the experiences narrated by the poet persona are neither a romance nor a fairy tale that occurred in some distant continent. The definite article "the" underlines the reality and the intensity of the definiteness captured with the article. The "harvested cornfields" (line5), "ripening yams" (line 6) "leguminous lilt" (line7) "swinging furious" (line 8) and "the lake" (line 16) are all beautiful experiences of naturalness of Africa in the time past that the poet persona takes poetic excursion into.

The vividness of this experience is heightened by the sequential arrangement of adjectives and nouns as modifiers and headwords respectively in stanzas 2 and 3:

$\mathrm{M}$

harvested

M

ripening

$\mathrm{M}$

leguminous

$\mathrm{M}$

$$
\text { swinging }
$$

M

gallant
$\mathrm{H}$

$$
\begin{array}{ll}
\text { cornfields } & \text { (line 5) } \\
\mathrm{H} & \\
\text { yams } & \text { (line 6) }
\end{array}
$$

$\mathrm{H}$

lilt

$\mathrm{H}$

furrows

(line 8)

$\mathrm{H}$

butterfly (line 11) 
Apart from "lilt", all the nouns are concrete demonstrating the concreteness of these encounters in the 'excursion'.

"Past" is thematic and its position foregrounded by its repetitive occurrence. In a five-stanza poem of 28 lines, only "past" occurred 16 times as an indirect pointer to the distal dislocation of the present from the past.

The poet persona deploys coinage in the adverbial, "tusklessly" from tusk (line 4) to vivify the greatness of the environment. Though elephant grass is so described here, it does not grow tusk. In this context, it is elongated to the size comparable to that of a live elephant.

\subsection{Farm-Born}

In the organizational patterning of the poems in the movement, "Home call", the poem "Excursion" precedes "Farm -Born". The tempo of narration and the experiences narrated are sustained in "Farm-Born". The poet persona, born in a peasant farm environment, savoured the freshness of the forest and all the elements of nature found in such a natural setting.

The similarity between the two poems can also be found in the modifier - head word, adjectivenoun relationship. The primary function of adjectives is to give a distributive and attributive picture of the noun modified. This function is reflective in the arrangement of some lines in the poem. It helps the poet avoid all forms of ambiguity and obscurity to imprint the experiences described on the readers' minds.

Examples include:

M

peasant

M

quickening

M

intricate

M

delicious

M

pendulous

M

ripening
$\mathrm{H}$

bred

(line1)

$\mathrm{H}$

earth

(line 4)

$\mathrm{H}$

path

(line 8)

$\mathrm{H}$

symmetry (line 16)

$\mathrm{H}$

promise

(line18)

$\mathrm{H}$

pawpaw

In the words of stringer (2019), lexical semantic analysis concentrates on content words. Though, he argues that the import of grammatical words in structures should be taken into consideration. In the poem "Farm Born" the poet persona deploys deliberately certain content words such as the main verb: "fondled the melon breasts", (line 5) adjective: "succulent ridges 
(line 6), noun: "dew call" (line10) noun: "iroko refuge" (line 11) and adjective: "fresh - felled forests" (line15). This deliberate selection of content words of intimacy is a reflection of the affinity between the persona and the natural environment where he was born and brought up.

The direct transfer from the local culture of 'iroko', in "iroko refuge" (line 11) and 'akee' in "akee apple colours" (line 17) heightens the intimate relationship between the poet persona and his peasant natural environment.

Noticeable in the poem is the direct translation of some expressions from Yoruba, the homeland of Osundare to English language. Example is found in the last stanza:

\author{
I have thrown open my kitchen door \\ and ask hunger to take a seat \\ my stomach a howling dump \\ for carolina rice.
}

The context involved here is that of freshness and originality. Carolina rice is locally produced without preservatives and chemicals associated with preserving rice in contemporary time. The smell of freshness emanating from the rice wets the locals' appetite and makes them hunger to consume the rice hence the direct translation above. It further re-echoes the freshness and originality of the environment described.

\title{
5.3. Ours to Plough not to Plunder
}

It is a poem where we are reminded that man is the owners of the earth and so needs not destroy the earth. The poem reveals enormous benefits we stand to enjoy by ploughing and not plundering our environment.

One striking linguistic element deployed in this poem is the verbal "let" repeatedly used in stanzas 2, 3 and 4. It introduces a polite imperative that serves the speech act of encouraging all and sundry to plough and not plunder the environment. Obeying this command will enrich our environment and the experiences will be interesting.

For example:

Let the sweat which swell earthroot

relieve heavy heaps of their tuberpus burdens

Let wheat fields raise their breadsome

Hands to the ripening sun

Let the papaw swell and swing (stanza 3). 


\section{The Eye of the Earth}

The implication is that the harvest will be rich and our crops will not be attacked by bacterial infection. The wheat fields will experience sun that will help them ripe properly and the pawpaw will grow normally and energy the swinging effect of the wind naturally.

In addition to the verbal "let" consistently used, some more verbal group loaded with actions suggestive of proper management of the natural resources include "plough" (line 1) "plant" (line 1) "relieve” (line7) "swing" (line 12) "spring” (line 14).

Osundare stylistically compounded some lexemes that ordinarily will occur separately in structures. Examples are "earthroot" (line 6) "tuberpus" (line 7) "wheatfields" (line 8) and grainhouse" (line 2). In English the head of a compound is normally the item on the right hand side of the compound..., the syntactic head is also the semantic head of the compound" (Katamba, 1994,p.73). In the example above, the head automatically becomes "root" "field" "pus" and "house" respectively. They serve the function of clarity of purpose for the poet. The field in this context translates to human environment that contains untapped resources buried deep in its root. Positive engagement of man in the environment will yield surplus "grains" for the "house".

Linguistic parallelism plays a foregrounding role in the two lines before the last:

$\mathrm{S}$

Ours

$\mathrm{S}$

Ours

\section{$\mathrm{P}$}

to work not to waste

$\mathrm{P}$

to man not to main

It is deployed to play summation and emphatic role of reminding the readers of the key message of the poem and which is that the earth belongs to man, to plough for his good and not to destroy it.

\subsection{Our Earth will not Die}

This poem is a summation of terrible activities of man on the natural environment that has adversely affected the earth. Notably is the business of multinational oil companies that has resulted in depletion of fish population, water hyacinth invasion, gas flaring beclouding the atmosphere, and oil spillage leading to poisoning of streams and rivers. The poem ends on a note of hope and optimism.

There is a remarkable repetition of the possessive adjective "our" all through the poem as can specifically be found in lines 7,17,21,30,34,35,47 and 48. Familiarly, possessive adjectives are used to show ownership. The poet persona through this repetitive device re-echoes man's position with the natural environment and in this repetition is hidden the optimistic vision of restoring the earth to its original form of naturalness, freshness and beauty.

Corroborating Gogio (2014) that man's environment encompasses material and non-material elements of the earth, including man and the supernatural, the poet persona personifies the earth as man, suffering different types of attack. He buttresses this image of attack with the semantic field of "killing' to include "lynched" (line 1) "slaughtered" (line 3) and "mauled" (line 5). The point made is further instantiated with a set of synonyms and near synonyms carefully selected 
for vividness. These include "killed" (line 11), "poisoned" (line 13) "coughing" (line 14), "wailing" (line 15), and "sobbing" (line 27).

Osundare's pre-occupations in this poem are encapsulated in the syntagmatic selection of some lexemes constituting complex noun phrases with modifying adjectives: "arsenic urine/from the bladder of profit factories" (lines 11-12). This points to the filth and pollution of the environment from the activities of the oil companies. Other examples include:

\author{
a poisoned stream staggers down the hills \\ coughing chaos in the sickly sea \\ the wailing whale, belly up like a \\ frying fish (lines 13-16)
}

The descriptiveness achieved from the semantic import of these structures is summarized in lack of drinkable water arising from oil spillage, destruction of aquatic life and general chaos in the entire eco-system.

In spite of this level of degradation, Osundare is optimistic that deliberate efforts by man can revive the earth and restore it to its original state. He supports this vision and hope with adjectivals and verbals of positivity and action such as "new" (line 36), "rise" (line 37), "twittering" (line 40) "dancing" (line 40), "blooming" (line 41) "jubilant" (line 44).

\title{
6. CONCLUSION
}

The researcher has engaged in doing detailed lexical semantic analysis of selected environmental poems from Osundare's poetry collection, The Eye of the Earth. The research has revealed the important roles of the definite article "the" as a determiner and modifier that underlines the definiteness and reality of the experiences captured in the poems. The study has also extensively investigated the significance of some selected lexemes in verbal, nominal, adjectival, and adverbial classes used in the poems especially as they aided the identification of different forms of environmental challenges and their adverse effects on the well-being of humanity.

The study also revealed some parallel linguistic structures and unusual compounding deployed in the poems to topicalize and foreground. The repetitive use of the adjectival "our" featuring in almost all the fact poem encapsulates Osundare's vision of re-awakening our consciousness of the fact that the environment is man's possession and as such, it is imperative not to destroy it but nurture it for the good of mankind.

\section{REFERENCE}

Adegbija, E. (1989). Lexico-semantic variation in Nigerian English. World Englishes, 8(2), 165-177. https://doi.org/10.1111 
Agofure, J.O (2016) Modern Nigerian poetry and the environment: An ecocritical study of selected poems of Tanure Ojaide, Niyi Osundare and Nnimmo Bassey.Ph.D Thesis. Department of English and Literary Studies. Ahmadu Bello University, Zaria.

Anyokwu, C. C. (2013). Sound semiotics of Osundare's poetry. CLCWeb: Comparative Literature and Culture, 15(1), 13 https://doi.org/10.7771/1481-4374.1994.

Anyokwu, C. C (2015) The essentials of Niyi Osundare's poetry. Transnational literature.8. (1) Retrieved from http://hdl.handle.net/2328/35648.

Butler, C.S. 1985. Systemic linguistics: theory and application: London: Balsford Academic and Educational.

Cruse, D.A (1986) Lexical semantics. Cambridge: Cambridge University Press.

Dick T.O (2016) Demystification of poetic language as a style in Niyi Osundare poetry. World Journal of English Languages. 16 ( 3). Retrived from http://wjel.scie.dupress. Com.

Dick T.O (2018) Graphology: An expressive poetic style of deviation in Niyi Osundare's poetry. Retrieved from wwwdiscoveryjournal.org.

Dobie, A. (2009). From theory to practice: An introduction to literary criticism. Retrieved from www.academia.edu/3461.

Elgezeery, G. M. A. (2013). Memory and Homecoming in Niyi Osundare's The Eye of the Earth. English Language and Literature Studies, 3(2), 62. http://dx.doi.org/10.5539/ells.v3n2p62.

Glotfelty, C., \& Fromm, H. (Eds.). (1996). The ecocriticism reader: Landmarks in literary ecology. University of Georgia Press.. Retrieved from https://books.google.com>... >general.

Gogoi, G. (2014). An ecocritical approach to Chinua Achebe's Things fall apart and Arrow of God. Journal of Humanities and Social Science, 19(11), 1-4.

Halliday, M.A.K. (1985). An introduction to functional grammar. $2^{\text {nd }}$ ed. London: Arnold Edward.

Jimmy, N. B. (2015). Eco-critical approach to literary text Interpretation. In International journal of innovation and scientific research. 18(2).369-378. Retrieved from http://www.ijisr-journals.org.

Katamba, F. (1994) English words. Great Britain : Routledge.

Lamidi, M. T. 2000. Aspects of Chomskyan grammar. Ibadan: Emman Publications.

Moolla, F. (2016) Nature of Africa : Ecocriticism and Animal Studies in Contemporary Cultural Forms. https://www.jstor.org/stable/10.18772/22016069131.

Murphy. M.L (2016) Lexical semantics. Retrieved from www.llas.ac.uk>resource>gpg.

Lyons, J (1977) Semantics. Cambridge: Cambridge University Press.

Nwagbara, U. (2013). Nature in the Balance: the commodification of the environment in Niyi Osundare's the eye of the earth. Nordic Journal of African Studies, 22(3), 196-212. 
Oloko,M.J (2017) A linguistic Analysis of metaphors in the poetry of Niyi Osundare. Ph.D Thesis,Department of English university of Lagos.

Osisanwo, W. 1999. An introductory analytical grammar of English. Lagos: Femolus- Fetop.

Osundare,N. (1986). The eye of the earth. Lagos: Heinemann.

Owomoyela, O. (1979) African literatures: An introduction. African Studies Association. Waltham.

Stringer, D. (2019) Lexical semantics: Relativity and transfer: Social sciences. Retrieved fromwww.igi-global.com $>$ chapter $>$ lexical semantics.

Wu, C .C.(2016) Toward an African-focused Eco-criticism: The Case of Nigeria. Ph.D Thesis, UniversityofNevada.https://schlarworks.unr.edu $>$ bitstream $>$ handle $>$ wu_unr_ 0139D_12011 